\title{
Richness, diversity and abundance of bats in small forest fragments of the Atlantic Forest in northern Parana, Brazil
}

\author{
Riqueza, diversidade e abundância de morcegos em pequenos \\ fragmentos florestais de Mata Atlântica no norte do Paraná, Brasil
}

\author{
Maíra Nunes Fregonezi ${ }^{1}$; Nelio Roberto dos Reis ${ }^{2}$; Bruna Karla Rossaneis ${ }^{3}$
}

\begin{abstract}
This study aims to investigate the correlation between the size of four forest fragments in northern Paraná with the richness, diversity and relative abundance of bats community. Monthly collections were performed for each fragment from July 2008 to June 2009, with the use of eight mist nets, comprising $160 \mathrm{~m}^{2}$ of exhibition area, totaling 192 hours. The capture effort was equal to $7,680 \mathrm{~m}^{2} / \mathrm{h}$. The richness was analyzed according to the number of species, the diversity was obtained by the Shannon-Wiener index and the relative abundance was calculated by dividing the total of individuals captured by the captures effort. Simple linear regressions were performed to verify the effect of the independent variable in relation to ecological parameters mentioned above. The largest fragment had a higher abundance and higher gross value of diversity index. It is possible that the adult individuals of uncommon species be the last in the area and that, due to the reduction of their habitats, their local populations will disappear in the future. Therefore, the maintenance of fragments, regardless of size, is essential for the conservation of bat communities.
\end{abstract}

Keywords: Bats. Fragmentation. Habitat loss. Preservation.

\section{Resumo}

O presente trabalho tem como objetivo verificar a correlação entre o tamanho quatro fragmentos florestais no norte do Paraná com a riqueza, diversidade e abundância relativa da comunidade de morcegos. Coletas mensais foram realizadas em cada fragmento de julho de 2008 a junho de 2009, com a utilização de oito redes de neblina, perfazendo $160 \mathrm{~m}^{2}$ de exposição, totalizando 192 horas. O esforço de captura foi igual a $7.680 \mathrm{~m}^{2} / \mathrm{h}$. A riqueza foi analisada de acordo com o número de espécies, a diversidade obtida pelo índice de Shannon-Wiener e a abundância relativa calculada pela divisão do total de exemplares capturados pelo esforço de captura. Regressões lineares simples foram aplicadas para verificar o efeito da variável independente em relação aos parâmetros ecológicos acima citados. O maior fragmento apresentou maior abundância e maior valor bruto do índice de diversidade. É possível que os indivíduos adultos de espécies pouco frequentes sejam os últimos em algumas áreas e que, por conta da redução de seus habitats, suas populações locais futuramente desapareçam. Portanto, a manutenção de fragmentos, independente de seu tamanho, é essencial para a conservação das comunidades de morcegos.

Palavras-chave: Quirópteros. Fragmentação. Perda de habitat. Preservação.

\footnotetext{
${ }^{1}$ Departamento de Biologia Animal e Vegetal, Universidade Estadual de Londrina. E-mail: mnfregonezi@hotmail.com (autor para correspodências)

${ }^{2}$ Departamento de Biologia Animal e Vegetal, Universidade Estadual de Londrina. E-mail: nrreis@uel.br

${ }^{3}$ Departamento de Biologia Animal e Vegetal, Universidade Estadual de Londrina. E-mail: bkrossaneis@yahoo.com.br
} 


\section{Introduction}

The overall process of habitat fragmentation has affected profoundly the bat communities that once inhabited nearly continuous areas and now need to survive in a landscape consisting of "isolated islands", mostly (MACARTHUR; WILSON, 1967). In the State of Paraná, the area covered by the original forest has been drastically reduced since 1930, due to the expansion of agriculture and urbanization. According to Fundação SOS Mata Atlântica and Instituto Nacional de Pesquisas Espaciais (INPE), in a report published in 2010, the remaining area of the biome is of $10.52 \%$, including sandbanks and mangroves, besides forests. A few fragments of original forest still exist and those that stand out for their size are the Mata dos Godoy State Park (680 ha), San Francisco State Forest (832.57 ha) and Monte Alegre Farm (126,373 ha), plus the last two major areas, the Iguaçu National Park (170,086.76 ha) and Serra do Mar Forest (386,000 ha), which still support a considerable diversity of bats (REIS; PERACCHI; SEKIAMA, 1999; SEKIAMA et al., 2001; FOGAÇA, 2003).

A relationship usually found for several taxonomic groups, is the species-area, which assumes a strong relationship between the area used by a community and the richness and diversity found (PAGLIA; FERNADEZ; DE MARCOJUNIOR, 2006). In the studied region, some works have aimed to compare the number of bat species with the size of the fragments, being among them: "What is best to keep the richness of bats (Mammalia, Chiroptera): a large forest fragment or multiple fragments of small size? (REIS et al., 2003); "Diversity of bats (Chiroptera: Mammalia) in forest fragments in the state of Parana, Brazil (REIS et al., 2000); "Is the area of the Arthur Thomas Park, with its 82.72 ha, sufficient to maintain viable chiropteran populations?"(FELIX et al., 2001). The authors mention that a large environment, with primary forests, is better structured to accommodate species than a small one, but they emphasize that apart from size, the quality of the fragment and the availability of resources also influence the amount of species, a fact which had already been observed in the Amazon by Zimmerman and Bierregaard (1986).

Another relationship that can be found is between fragment area and the relative abundance of species. Rare is the research that aims to accomplish this association in Paraná, being the one entitled "Richness and abundance of bat species in fragments of semideciduous forest of Paraná river, southern Brazil (ORTÊNCIO-FILHO, 2008), one of the most current. Particular care should be taken when considering the abundance of some communities, as in frugivores, this seems to be directly related to the spatial and temporal availability of fruit consumed by them (GAZARINI, 2008). We believe that for a real analysis on the abundance, seasonal samples should be performed.

This paper aims to: analyze the diversity, richness, relative abundance of bats from four small fragments and verify if there is a correlation between the size of the fragments and the variables mentioned.

\section{Material and Methods}

Study Area

Samples were taken at four forest fragments, distributed in three municipalities in northern Paraná (Figure 1):

1) Sítio Cazado $\left(23^{\circ} 14^{\prime} 28\right.$ "S/51 $\left.22^{\prime} 20^{\prime \prime W}\right)$ : located in the municipality of Rolândia, it has about 15 ha and is surrounded by agricultural activities;

2) Horto Florestal of the State University of Londrina $\left(23^{\circ} 19^{\prime} 45^{\prime \prime} \mathrm{S} / 51^{\circ} 12^{\prime} 25^{\prime \prime} \mathrm{W}\right)$ : located westbound to the city of Londrina, with 10.4 hectares; it is in the outskirts of the city;

3) Sitio Santana $\left(23^{\circ} 20^{\prime} 7^{\prime \prime} \mathrm{S} / 51^{\circ} 16^{\prime} 44^{\prime \prime} \mathrm{W}\right)$ : located in the municipality of Cambé; it has 5.9 ha and is surrounded by agricultural activities; 
4) Parque Municipal Histórico de Cambé $\left(23^{\circ} 17^{\prime} 56^{\prime \prime} \mathrm{S} / 51^{\circ} 16^{\prime} 43^{\prime \prime} \mathrm{W}\right)$ : it borders BR-369 to the north, with $5.4 \mathrm{ha}$; it is near the urban area surrounded by farms and agricultural activities.

Figure 1 - Location of forest fragments in northern Paraná

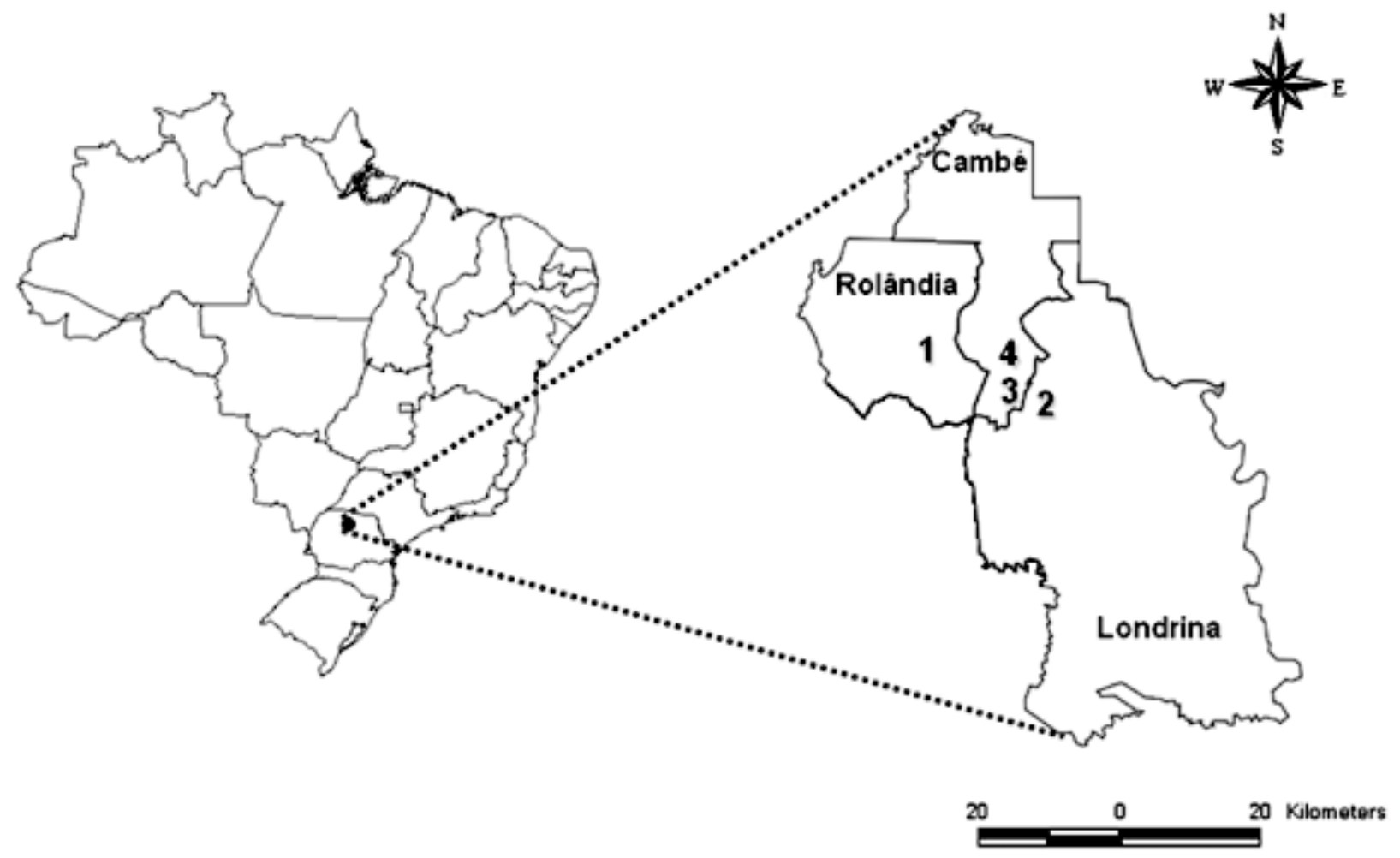

Fonte: dos autores.

The four areas are close to each other, with maximum linear distance of $20 \mathrm{~km}$, and therefore have similar characteristics in relation to climate and vegetation. According to Köppen's classification, the climate is humid subtropical and all fragments are remnants of semideciduous forest, which has highly diverse tree flora, compared to other forest types (GUSSON, 2007). Originally, characteristic plant species were found, such as peroba-rosa (Aspidosperma polyneuron Müll. Arg.), pau d'alho
(Gallesia integrifolia Spreng.), paineira (Chorisia speciosa St. Hil), primavera (Bougainvillea glabra), canjanara (Cabralea canjerana (Vell.) Mart), cedro (Cedrella sp.), gurucaia (P. rigida), ingá (Inga sp.), figueira (Ficus sp.), jerivá (Syagrus romanzoffiana (Chamisso)), palmito (Euterpe edulis Martius) and cinnamon (Nectandra puberula Schott) (SILVEIRA, 2006), but currently there are few individuals. The fragments are filled by species of Solanaceae, Piperaceae and Cecropiaceae (pers. 
obs.).

\section{Methodology}

A monthly sampling was performed for each fragment, for the period of July 2008 to June 2009. We used eight mist nets for collection, comprising $160 \mathrm{~m}^{2}$ of exhibition area, which remained open during the first four hours of the night, totaling 192 hours during a year of study.

The capture effort was equal to $7,680 \mathrm{~m}^{2} / \mathrm{h}$, calculated by multiplying the net area $\left(\mathrm{m}^{2}\right)$, by the total number of nets per night, by the total hours that remained open during the night, as proposed by Straube and Bianconi (2002).

The nets were set on trails and searched at intervals of 15 minutes, to avoid the stress of animals stuck to the net and prevent damage to the nets, caused by them.

The captured animals were identified in the field with the aid of keys produced by Vizotto and Taddei (1973), Jones and Carter (1976) and Reis et al. (1993).

\section{Data Analysis}

The richness was analyzed according to the number of species. The relative abundance of bats for each fragment was calculated by dividing the total of individuals captured by the capture effort, adapting to the one proposed by Aguirre (2002). The diversity was obtained using Shannon Winner $\left(\mathrm{H}^{\prime}\right)$ calculated from the program DiVES 2.00.0105 2009.

Simple linear regressions were performed to verify the effects of the independent variable (area) in relation to species richness, diversity and abundance, with a significance level of 0.05 , which were calculated using the program R 2.12.1 2010.

\section{Results}

Four hundred and ninety-five individuals from 11 species were captured, distributed among the families Phyllostomidae (92.72\%) and Vespertilionidae (7.28\%). Among the bats, Sturnira lilium (E. Geoffroy, 1810) proved to be the most frequent captures, with $40 \%$ of individuals, followed by Artibeus lituratus (Olfers, 1818) (23.9\%), Carollia perspicilata (Linnaeus, 1758) (23.2\%) and Myotis nigricans (Schinz, 1821) (7.4\%). The rest of the species had a low rate of capture, adding up to $5.5 \%$ (Table 1). 
Table 1 - Species, number and percentage of individuals captured in the four forest fragments during the period of July 2008 to June 2009.

\begin{tabular}{|c|c|c|c|c|c|c|c|c|c|c|}
\hline \multirow{2}{*}{ Recorded species } & \multicolumn{2}{|c|}{$\begin{array}{c}\text { Sitio } \\
\text { Cazado } \\
(15 \text { ha) }\end{array}$} & \multicolumn{2}{|c|}{$\begin{array}{c}\text { Horto } \\
\text { Florestal } \\
(10 \mathrm{ha})\end{array}$} & \multicolumn{2}{|c|}{$\begin{array}{c}\text { Sitio } \\
\text { Santana } \\
(5,9 \text { ha })\end{array}$} & \multicolumn{2}{|c|}{$\begin{array}{c}\text { Parque } \\
\text { Municipal } \\
(5,4 \text { ha })\end{array}$} & \multicolumn{2}{|c|}{ TOTAL } \\
\hline & $\mathbf{N}$ & $\%$ & $\mathbf{N}$ & $\%$ & $\mathbf{N}$ & $\%$ & $\mathbf{N}$ & $\%$ & $\mathbf{N}$ & $\%$ \\
\hline \multicolumn{11}{|l|}{ Phỵllostomidae family } \\
\hline \multicolumn{11}{|l|}{ Desmodontinae Subfamily } \\
\hline Desmodus rotundus (E Geoffroy, 1810 ) & 2 & 0,9 & & & & & & & 2 & 0,4 \\
\hline \multicolumn{11}{|l|}{ Glossophaginae Subfamily } \\
\hline Glossophaga soricina (Pallas, 1766) & & & 1 & 0,73 & & & & & 1 & 0,2 \\
\hline \multicolumn{11}{|l|}{ Carollinae Subfamily } \\
\hline Carollia perspicillata (Linnaeus, 1758) & 77 & 35 & 10 & 7,35 & 15 & 30,6 & 12 & 13,6 & 114 & 23,2 \\
\hline \multicolumn{11}{|l|}{ Phyllostominae Subfamily } \\
\hline Phyllostomus hastatus (Pallas, 1767) & & & 1 & 0,73 & & & & & 1 & 0,2 \\
\hline \multicolumn{11}{|l|}{ Stemodermatinae Subfamily } \\
\hline Artibeus lituratus (Olfers, 1818) & 29 & 13 & 43 & 31,6 & 16 & 32,7 & 30 & 34,1 & 118 & 23,9 \\
\hline Artibeusfimbriatus Gray, 1838 & 2 & 0,9 & 1 & 0,73 & & & 5 & 5,68 & 8 & 1,61 \\
\hline Artibeus planirostris (Spix, 1823) & 5 & 2,3 & & & & & & & 5 & 1 \\
\hline Platyrrhinus lineatus (E. Geoffroy, 1810) & 8 & 3,6 & & & & & & & 8 & 1,61 \\
\hline Sturniralilium (E. Geoffroy, 1810) & 75 & 34 & 73 & 53,7 & 16 & 32,7 & 36 & 40,9 & 200 & 40 \\
\hline Vampyressa pusilla (Wagner, 1843) & & & 2 & 1,48 & & & & & 2 & 0,4 \\
\hline \multicolumn{11}{|l|}{ Vespertilionidae Family } \\
\hline \multicolumn{11}{|l|}{ Vespertilionae Subfamily } \\
\hline Myotis nigricans (Schinz, 1821) & 24 & 11 & 5 & 3,68 & 2 & 4 & 5 & 5,68 & 36 & 7,4 \\
\hline TOTAL & 222 & 100 & 136 & 100 & 49 & 100 & 88 & 100 & 495 & 100 \\
\hline
\end{tabular}

Fonte: dos autores.

The species richness did not achieve significant association with the area $(\mathrm{R} 2=0.7414 ; \mathrm{p}>0.05)$, as well as species diversity by the Shannon index $(\mathrm{R} 2=0,445, \mathrm{p}>0.05)$. However, we found that diversity was small in all the fragments, since the lower the index value, the lower the diversity sampled. However, the Sítio Cazado, the largest fragment (15ha), had the highest gross value of the index. The relative abundance showed a significant relationship with the size of the fragments $(\mathrm{R} 2=$ $0.9313, \mathrm{p}<0.05)$ (Table 2). 
Table 2 - Species richness, relative abundance and diversity index found in the four studied remnants.

\begin{tabular}{|c|c|c|c|c|c|}
\hline & $\begin{array}{c}\text { Number of } \\
\text { individuals }\end{array}$ & $\begin{array}{c}\text { Number of } \\
\text { species }\end{array}$ & Effort & $\begin{array}{c}\text { Relative } \\
\text { aundance } \\
(\mathbf{x l 0 0 0})\end{array}$ & $\begin{array}{c}\text { Shannon } \\
\text { Winner Index }\end{array}$ \\
\hline Cazado & 222 & 8 & $7.680 \mathrm{~m}^{2} / \mathrm{h}$ & 28.9 & 0.6646 \\
\hline Horto & 136 & 8 & $7.680 \mathrm{~m}^{2} / \mathrm{h}$ & 17.7 & 0.5133 \\
\hline Santana & 49 & 4 & $7.680 \mathrm{~m}^{2} / \mathrm{h}$ & 6.38 & 0.5315 \\
\hline Parque & 88 & 5 & $7.680 \mathrm{~m}^{2} / \mathrm{h}$ & 11.48 & 0.5777 \\
\hline
\end{tabular}

Fonte: dos autores.

\section{Discussion}

There was a greater capture of individuals of the family Phyllostomidae, because the nets were set up in the understory, which favors the capture of bats using this stratum and where the main plants used as food for this family (TAVARES, 1999; SÁNCHEZ, 2001; STRAUBE; BIANCONI, 2002). These bats are adapted to the use of secondary plants such as Solanaceae, Piperaceae, Cecropiaceae, which are constant in these types of altered fragments (MARINHO-FILHO, 1991; MULLER; REIS, 1992; WILLIG; CAMILO; NOBILE, 1993; ZORTÉA; CHIARELLO, 1994; PASSOS et al., 2003). Still, phyllostomids represent $47 \%$ of existing species in the state of Paraná (MIRETZKI, 2003). Regarding vespertilionids, it was expected a smaller number of individuals, because they detect and avoid the nets (GREENHALL; PARADISO, 1968; PEDRO; TADDEI, 1997; STRAUBE; BIANCONI, 2002).

The species richness did not achieve significant association with the area, as well as what was found for the diversity, contrary to expectations, because according with "island biogeography theory", proposed by MacArthur and Wilson (1967), which was adapted to terrestrial environments, larger areas tend to have more richness for they support a larger diversity of habitats. The increase in specific species richness may be related to productivity and food availability, but a more productive environment may have a higher rate of supply of resources, but not a greater variety. This leads to an increase in the number of individuals per species, and not an increase in the number of species (TOWNSEND; BEGON; HARPER, 2006).

According to relative abundance, it was observed a positive association with the size of the fragments. In a study performed in French Guiana, with nectar and fruit bats, it was found that the anthropic alterations have caused a reduction in the abundance of some species, usually rare (COSSON; PONS; MASSON, 1999), corroborating with our results, showing that larger environments, have higher abundances. The fragmentation can influence the abundance of bats with some adaptation to altered environments, as in Artibeus planirostris (Spix, 1823), A. lituratus (Olfers, 1818), C. perspicillata (Linnaeus, 1758), S. lilium (E. Geoffroy, 1810) and M. nigricans (REIS et al., 2003). Therefore, it is possible that the adult individuals of uncommon species be the last in the area and that, due to the reduction of their habitats, their local populations will disappear in the future (ORTÊNCIO-FILHO, 2008).

Deforestation causes firstly immediate loss of the species, then the isolation of populations. In the long term it is possible to observe the action of "vortex" of extinction, such as loss of genetic variability by inbreeding and loss of flexibility for 
evolutionary responses, which are factors that cause the disappearance of local populations (GILPIN; SOULÉ, 1986). Despite this, one can see that eleven species were captured in altered habitats, that is, they can establish themselves even in small and fragmented environments. However, the largest fragment showed greater abundance, and diversity was small in all fragments.

It is also worth mentioning that bats are considered K strategists, as they have low reproductive capacity, low number of offspring and long lifetime, and they respond more strongly to the biotic components of the ecosystem (FINDLEY, 1993), therefore requiring a more stable environment to survive. Thus, we conclude that there is an increasing need for reforestation and maintenance of existing fragments, since if the conservation of habitats does not occur in the near future, there will only remain populations of well adapted species.

\section{Acknowledgements}

We grateful to Department of Animal and Plant Biology at the State University of Londrina and to the CAPES for the financial support.

\section{References}

AGUIRRE, L. F. Structure of a neotropical savana bat community. Journal of Mammalogy, Lawrence, v. 83, n. 3, p. 775-784, 2002.

COSSON, J. F.; PONS, J. M.; MASSON, D. Effects of forest fragmentation on frugivorous and nectarivorous bats in French Guiana. Journal of Tropical Ecology, Cambridge, v. 15, n. 4, p. 515534, 1999.

FELIX, J. S.; REIS, N. R.; LIMA, I. P.; COSTA, E. F.; PERACCHI, A. L. Is the area of the Arthur Thomas Park, with its 82.72 ha, sufficient to maintain viable chiropteran populations? Chiroptera Neotropical, Belo Horizonte, v. 7, n. 1/2, p. 129132, 2001.

FINDLEY, J. S. Bats: a community perspective. Cambridge: Cambridge University Press, 1993.

FOGAÇA, F. N. O. Chiroptera (Mammalia) do parque florestal Rio da Onça (Matinhos, PR). 2003. 56 f. Dissertação (Mestrado em Ciências Biológicas) - Universidade Federal do Paraná, Curitiba, 2003.

GAZARINI, J. Estrutura da comunidade de morcegos (Mammalia, Chiroptera) em fragmentos urbanos de Maringá, Paraná, Brasil. 2008. 110 f. Dissertação (Mestrado em Ciências Biológicas) - Universidade Estadual de Londrina, Londrina, 2008 .

GILPIN, M. E.; SOULÉ, M. E. Minimum viable populations: processes of species extinction. In: SOULÉ, M. E. Conservation biology: the science of scarcity and diversity. Sunderland: Sinauer Associates, 1986. p. 19-34.

GREENHALL, A. M.; PARADISO, J. L. Bats and bat banding. Washington: Bureau of Sport Fisheries and Wild, 1968.

GUSSON, A. E. Composição florística e estrutura fitossociológica da comunidade arbustivoarbórea de uma floresta estacional semidecidual no município de Ipiaçu. 2007. 40 f. Monografia (Especialização) - Universidade Federal de Uberlândia, Uberlândia, 2007.

INSTITUTO NACIONAL DE PESQUISAS ESPACIAIS (INPE). Atlas dos remanescentes florestais da Mata Atlântica periodo 2008-2010. 2010. Disponivel em: $<$ http://www.inpe.br/noticias/ arquivos/pdf/atlasrelatoriofinal.pdf $>$. Acesso em: 6 jun. 2011.

JONES, J. K.; CARTER, D. C. Annotated checklist with keys to subfamilies and genera. In: BAKER, R. J.; JONES, J. K.; CARTER, D. C. (Ed.). Biology of bats the new world family 
Phyllostomatidae. Lubbock: Texas Tech University, 1976. p. 7-38.

MACARTHUR, R. H.; WILSON, E. O. The theory of Island Biogeography. Princeton: University Press, 1967.

MARINHO- FILHO, J. S. The coexistence of two frugivorous bat species and the phenology of their food plants in Brazil. Journal of Tropical Ecology, Cambridge, v. 7, p. 59-67, 1991.

MIRETZKI, M. Morcegos do estado do Paraná, Brasil (Mammalia, Chiroptera): riqueza de espécies, distribuição e síntese do conhecimento atual. Papéis Avulsos de Zoologia, São Paulo, v. 43, n. 6, p. 101138, 2003.

MULlER, M. F.; REIS, N. R. Partição de recursos alimentares entre quatro espécies de morcegos frugívoros (Chiroptera, Phyllostomidae). Revista Brasileira de Zoologia, Curitiba, v. 9, n. 3/4, p. 345-355, 1992.

ORTÊNCIO-FILHO, H. Riqueza de espécies e padrão horário e sazonal de capturas dos morcegos em fragmentos de floresta estacional semidecidual do alto rio Paraná, Brasil. 2008. Tese (Doutorado em Ecologia de Ambientes Aquáticos Continentais) - Universidade Estadual de Maringá, Maringá, 2008.

PAGLIA, A. P.; FERNANDEZ, F. A. S.; DE MARCO-JUNIOR, P. Efeitos da fragmentação de Habitats: quantas espécies, quantas populações, quantos indivíduos e serão eles suficientes? In: ROCHA, C. F, D.; BERGALlO, H. G.; VAN SLUYS, M.; ALVES, M. A. S. Biologia da conservação: essências. São Carlos: RIMA, 2006. p. 281-316.

PASSOS, F. C.; SILVA, W. R.; PEDRO, W. A.; BONIN, M. R. Frugivoria em morcegos (Mammalia, Chiroptera) no Parque Estadual Intervales, sudeste do Brasil. Revista Brasileira de Zoologia, Curitiba, v. 20, n. 3, p. 511-517, 2003.
PEDRO, W. A.; TADDEI, V. A. Taxonomic assemblage of bats from Panga reserve, southeastern Brazil: abundance patterns and trophic relations in the Phyllostomidae (Chiroptera). Boletim do Museu de Biologia Mello Leitão, Santa Teresa, n. 6, p. 3-21, 1997.

REIS, N. R.; BARBIERI, M. L. S.; LIMA, I. P.; PERACCHI, A. L. What is best to keep the richness of bats (Mammalia, Chiroptera): a large forest fragment or multiple fragments of small size? Revista Brasileira de Zoologia, Curitiba, v. 20, n. 2, p. 225-230, 2003.

REIS, N. R.; MULLER, M. F.; SOARES, E. S.; PERACCHI, A. L. Lista e chave de Quirópteros do Parque Estadual Mata do Godoy e Arredores, Londrina, Pr. Semina: Biológicas/Saúde, Londrina, v. 14, n. 2, p. 120-126, 1993.

REIS, N. R.; PERACCHI, A. L.; SEKIAMA, M. L. Morcegos da fazenda Monte Alegre, Telêmaco Borba, Paraná (Mammalia, Chiroptera). Revista Brasileira de Zoologia, Curitiba, v. 16, n. 2, p. 501505. 1999.

REIS, N. R.; PERACCHI, A. L.; SEKIAMA, M. L.; LIMA, I. P. Diversity of bats (Chiroptera: Mammalia) in forest fragments in the state of Parana, Brazil. Revista Brasileira de Zoologia, Curitiba, v. 17, n. 3, p. 696-704, 2000.

SÁNCHEZ, M. M. Morcegos fitófagos urbanos: relações tróficas, estrutura e distribuição das espécies no campus universitário da Universidade Federal de Minas Gerais, Belo Horizonte, durante a estação seca do ano. 2001. 65 f. Dissertação (Mestrado em Ecologia) - Instituto de Ciências Biológicas, Universidade Federal de Minas Gerais, Belo Horizonte, 2001.

SEKIAMA, M. L.; REIS, N. R.; PERACCHI, A. L.; ROCHA, V. J. Morcegos do parque nacional do Iguacu, Parana (Mammalia, Chiroptera). Revista Brasileira de Zoologia, Curitiba, v. 18, n. 3, p. $794-$ 754, 2001.

SILVEIRA, M. A vegetação do parque estadual 
Mata dos Godoy. In: TOREZAN, J. M. D. A ecologia da Mata dos Godoy. Londrina: ITEDES, 2006.

STRAUBE, F. C.; BIANCONI, G. V. Sobre a grandeza e a unidade utilizada para estimar esforço de captura com utilização de redes-de-neblina. Chiroptera Neotropical, Belo Horizonte, v. 8, n. 1/2, p. 150-152, 2002.

TAVARES, V. C. Ecomorfologia do vôo, dietas das espécies e composição de uma taxocenose de morcegos (Mammalia:Chiroptera) do Parque Estadual do Rio Doce, leste de Minas Gerais, sudeste do Brasil. 1999. 111 f. Dissertação(Mestrado em Ecologia. Instituto de Ciências Biológicas) - Universidade Federal de Minas Gerais, Belo Horizonte, 1999.

TOWNSEND, C. R.; BEGON, M.; HARPER, J. P. Fundamentos em ecologia. Porto Alegre: ARTMED, 2006.

VIZOTTO, L. D.; TADDEI, V. A. Chave para determinação de quirópteros brasileiros. Boletim de Ciências, São José do Rio Preto, v. 1, p. 1-72, 1973.

WILLIG, M. R.; CAMILO, G. R.; NOBILE, S. J. Dietary overlap in frugivorous and insectivorous bats from edaphic cerrado habitats of Brazil. Journal of Mammalogy, Lawrence, v. 74, n. 1, p. 117-128, 1993.

ZIMMERMAN, B. L.; BIERREGAARD, R. O. Relevance of the equilibrium theory of island biogeography with an example from Amazonia. Journal of Biogeography, Oxford, v. 13, p. 133-143, 1986.

ZORTÉA, M.; CHIARELLO, A. G. Observations on the big fruit-eating bat, Artibeus lituratus, in an Urban Reserve of South-east Brazil. Mammalia, Paris, v. 58, n. 4, p. 665-670, 1994. 
